\title{
To what extent do teachers use school homework, as a method of teaching-learning in pre-primary schools?
}

\begin{abstract}
Pre- primary school children need positive early learning experiences to help their intellectual, social and emotional development. This lays the foundation for later school success. As a learning strategy, pre-primary school teachers give school homework to help children practice what they learn in class. Despite many studies carried out on benefits of school homework in primary and secondary school levels, researchers claim that school homework is not beneficial to pre-primary school children. This is because they are already tired after being in school the whole day and they need time to relax and play. The study was carried out in Ruiru Division, Kiambu County. The design of the study was descriptive research design. This paper explores homework as a method of teaching. The study population was pre-primary school teachers in Ruiru Division. Simple random sampling was used to select a sample of 45 pre-primary schools from which 153 teachers were selected for the study. The data was collected through questionnaires which were administered to the teachers. A pilot study was conducted in one public and one private school which were not included in the sample. The data was then analyzed using qualitative and quantitative methods where the information obtained was organized into themes and concepts using Statistical Package for the Social Sciences (SPSS). Teachers believed that homework prompts improved academic performance. The study recommended that teachers should ensure they adhere to ECDE guidelines for appropriate teaching-learning methods. It was also recommended that school administrators should collaborate with District Center for Early Childhood Education (DICECE) to sensitize teachers on the impact on use of school homework as a teaching-learning method.
\end{abstract}

Keywords: school homework, research literature, pre-primary school, information, homework, assignments, grades, learner's opportunity, skill, respondents, qualitative methods, quantitative methods
Special Issue - 2018

\section{Kinuthia Lucy Wanyora, Catherine Gakii Murungi, Esther Njeri Waithaka \\ Kenyatta University, Department of Early Childhood Studies, Kenya}

Correspondence: Catherine Gakii Murungi, Department of Early Childhood Studies, Kenyatta University, PO-43844-00 I00, Nairobi, Kenya, Email Catherine_gakii@yahoo.com

Received: July 12, 2018 | Published: December 31, 2018

\section{Introduction}

The recent review of school homework research literature conducted by Cameron \& Bartel $^{1}$ claims that most researchers adopt the definition offered by Cooper ${ }^{2}$ because it is clear and concise. Cooper $^{2}$ has defined school homework assignments as tasks set by teachers for learners to complete outside normal lessons usually at home in the evenings. Common school homework assignments may include reading, writing to be completed, problems to be solved or other skills to be practiced. Learners may complete school homework alone, with other learners or with their parents and other family members. According to Murungi and Muthee ${ }^{3}$ some school homework is designed to give learners opportunity to practice skills taught in class, promote good working habits and a sense of responsibility. Petall, Cooper \& Wynn ${ }^{4}$ argue that school homework is beneficial to some group of learners though it primarily benefits learners in the higher grades than those in elementary levels. This study sought to establish the factors that influence teachers to give school homework to pre-primary school children.

\section{Use of school homework as a method of teaching- learning in pre-primary schools}

The following section discussed the impact on use of school homework as a method of teaching-learning in Pre-primary schools. Though the pros and cons of school homework have been debated for many years, school homework continues to be given to learners often because of a longstanding assumption that it is beneficial to them. Most of the arguments are based on the fact that school homework is good for learners because it teaches them to be responsible and that it develops a strong work ethic. It is said when learners have a lot of school homework, it is a sign of rigorous curriculum and a good teacher. ${ }^{6}$ Most parents, learners and teachers have strong opinions about the usefulness of school homework which has led to significance conflict and debate. In recent years, this conflict has intensified as elementary school learners have increasingly been assigned school homework (Loveless, 2003). ${ }^{7}$ Moreover the current research does not support these increasing school homework demands on young children. Most studies of school homework show either a negative impact or no impact on achievement of elementary school learners. This has led to a number of authors to strongly advocate severe reduction or elimination of school homework especially to younger children. ${ }^{8-10}$

Researcher has established that school homework has positive effects on learning particularly at the middle and secondary school levels. ${ }^{11,12}$ Effectiveness of school homework is enhanced by providing learners with choices among school work tasks, which will result in higher motivational and performance outcomes, learners' autonomy and intrinsic motivation. ${ }^{4}$ Kralovec and Buell ${ }^{13}$ have commented that many educators and parents continue to support the use of school homework because they believe it will lead to academic achievement they further argue that there is no real evidence to support this position since many school homework researchers admit that the academic 
achievement of elementary learners does not improve as a result of doing school work at home. Kralovec and Buell ${ }^{13}$ thus suggest that doing school homework can actually be detrimental if it requires learners to complete activities that they are not developmentally prepared to do.

In his study, Cooper ${ }^{14}$ stressed that all young children should be doing school homework but the amount and type should vary according to their developmental level and home circumstances. School homework for pre-primary school children should be short leading to success without much struggle for children to enjoy. Age appropriate pre-primary school homework ideas they include applying colour to pictures, writing their names several times or listing items that start with a specific letter. The findings of these studies show that there is pre-primary school homework involving suitable activities in the Western World. The current study was to investigate on the use of school homework as a method of teaching-learning in pre-primary schools in Ruiru Division, Kiambu County. ${ }^{14}$

\section{Methods}

The study adopted descriptive research design. Descriptive research design is a method of collecting information by interviewing or administering questionnaires to a sample of individuals. ${ }^{15}$ This design was found appropriate since the study involved collecting information through answering questions that were descriptive in nature concerning impact on use of school homework as a method of teaching-learning in pre-primary schools. The study was conducted in Ruiru Division, Kiambu County. The division was purposely selected for the study because it is a densely populated area with many preprimary school age children from a diversity of ethnic cultures. Purposive sampling was also used to select Ruiru Division because it borders Nairobi County resulting to teachers using school homework as a teaching-learning method due to high competition of Standard One intake. Ruiru Division is an industrialized area with many public and mushrooming private pre-primary schools. The division comprises Ruiru Zone with no other educational zones. The study targeted a population of 509 pre-primary school teachers in Ruiru Division, Kiambu County. This comprised of 60 teachers from public pre-primary schools and 449 from private pre-primary schools.

\section{Sampling techniques}

Ruiru Division was purposely selected and stratified random sampling was used to select the schools where the study was conducted. The criterion used for stratification was type of school. The sampling frame was drawn from a list of all pre-primary schools in the division found at Ruiru District Centre for Early Childhood Education (DICECE) office. The schools were categorized into two strata namely public and private pre-primary schools. Stratified random sampling was appropriate in this case because the sample was selected in such a way as to ensure that the groups were represented in the sample in proportion to their number in the population. ${ }^{15}$

\section{Sample size}

Simple random sampling was used to select a representative sample of 9 public pre-primary schools and 36 private pre-primary schools representing $30 \%$ of the total population of the pre-primary schools in Ruiru Division. The researcher selected $30 \%$ of preprimary school teachers from both private and public schools. According to Orodho ${ }^{15} 30 \%$ of the total population is a number within the acceptable representative sample. A total of 153 teachers were sampled out of which 18 of the teachers were from the public preprimary schools while the remaining 135 teachers were from private pre-primary schools.

\section{Data analysis}

The data obtained from the respondents was recorded in readiness for analysis. The research involved qualitative and quantitative methods. Qualitative data obtained from open-ended questions was analyzed by coding and organizing into themes and concepts. Statistical Package for the Social Sciences (SPSS) was used for data analysis. The data was analyzed using descriptive statistics such as frequency distribution and percentages. The analyzed data was presented in form of frequency tables, bar graphs and pie charts.

\section{Logistical and ethical consideration}

The researcher obtained an introductory letter from Kenyatta University and used the letter to get research permit from the Ministry of Education, Science and Technology. The permit was then taken to the District Education Office Ruiru, then to the school administrators. The researcher familiarized herself with the respondents and sought consent from them to voluntarily assist in filling the questionnaire. The researcher thereafter informed them the purpose of the study. Respondents were assured that the information they would give was to be treated with confidentiality.

\section{Findings (general information)}

\section{Teachers' Demographic Information}

The demographic information required from the respondents included age, gender, professional qualifications, teaching experience and type of teacher training. This information is presented in the following sub-sections:-

\section{Type of school}

Schools were categorized as either public or private with the number of teachers involved in the study as presented in Figure 1. Majority (84\%) of the pre-primary school teachers who were involved in this study were from private schools while the rest were from public schools in Ruiru Division, Kiambu County (Figure 1).

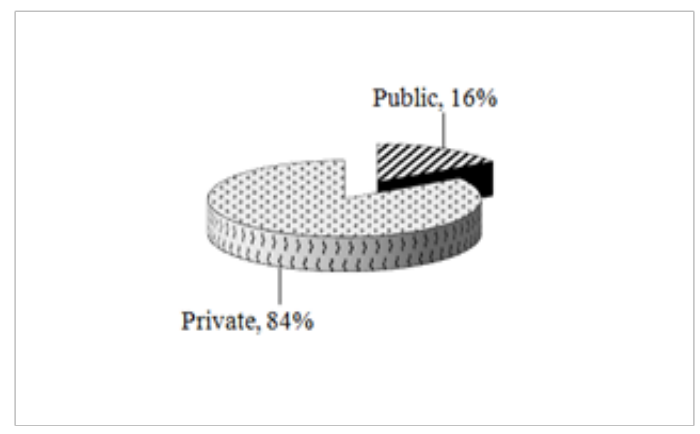

Figure I Type of schools.

\section{Gender of the respondents}

The researcher sought to establish the gender of the respondents and the responses are highlighted in Figure 2. Of all the respondents involved in the study, $85 \%$ of them were females while the rest of their counterparts were males (Figure 2). 


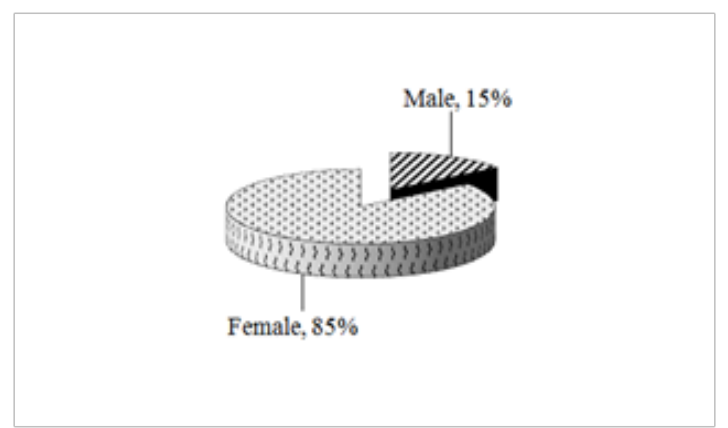

Figure 2 Gender of respondents.

\section{Age of the respondents}

The age of respondents was as depicted in Figure 3. Figure 3 shows that half of the respondents were aged between 31-40 years, followed by those aged between 21-30 years, while below a quarter of the respondents were 41 years and above. The findings indicate that majority of the respondents were between 31-40 years of age (Figure $3)$.

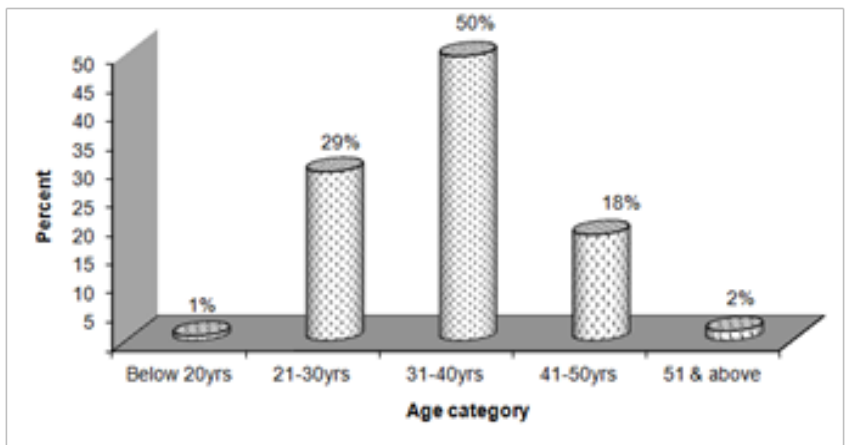

Figure 3 Age of the respondents.

\section{Pre-primary school teachers and use of school homework in teaching-learning}

The focused on use of school homework in relation to the following dimensions:-

\section{A. Assigning of school homework to children in class}

The study sought to establish the extent to which teachers use school homework as method of teaching-learning in pre-primary schools. The results were as presented in Figure 4. A vast majority of teachers (114) said that they assigned school homework to children in their classes with only (5) of them saying that they did not assign any. The results suggest that most teachers used school homework as a method of teaching-learning in pre-primary schools. The study findings confirm results of a study done by Loveless ${ }^{7}$ who found that elementary school learners have increasingly been assigned school homework. Vatterott ${ }^{6}$ carried out a study on school homework and found that when learners have a lot of school homework, it is a sign of rigorous curriculum and a good teacher. The study by Kralovec and Buell ${ }^{13}$ also indicated that many educators and parents continued to support the use of school homework because they believe it leads to academic achievement. Out of 114 pre-primary school teachers who reported that they assigned school homework to children in their classes, 105 teachers said that they assigned school homework to children every day while 9 of them said that they did not assign homework on daily basis (Figure 4).

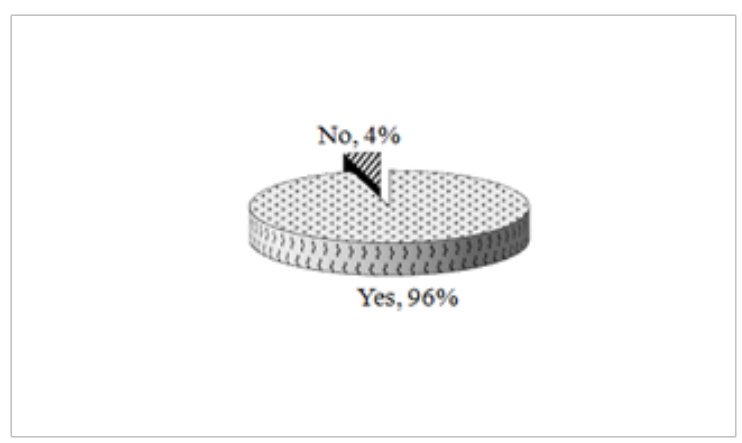

Figure 4 Assigning of school homework to children.

\section{B. Reasons for not assigning school homework}

The five percent of the respondents who never assigned homework to children were asked to state the reasons why they failed to assign school homework. Their responses were as presented in Table 1. The results in Table 1 , results reveal that $5 \%$ of the respondents gave reasons why they did not assign school homework with $2 \%$ indicating that children should choose what to do while the rest gave out reasons as presented in table 4 . The findings of this study showed that not all teachers assigned school homework. This is consistent with the findings of Patall, Cooper and Wynn ${ }^{4}$ who claimed that effectiveness of school homework is enhanced by providing learners with choices among school homework tasks. They stressed that this would result in higher motivational and performance outcomes, learners' autonomy and in intrinsic motivation. Contrary to this stance, Bennett and Kalish $^{8}$ in their research in United States argued that homework had little value and was actually harmful for children under the age of five years (Table 1).

Table I Number of pre-primary schools and teachers sampled

\begin{tabular}{llll}
\hline Type of school & $\begin{array}{l}\text { Total number } \\
\text { of schools }\end{array}$ & $\begin{array}{l}\text { No. of schools } \\
\text { sampled }\end{array}$ & $\begin{array}{l}\text { No. of teachers } \\
\text { sampled }\end{array}$ \\
\hline $\begin{array}{l}\text { Public pre- } \\
\text { primary schools }\end{array}$ & 30 & 9 & 18 \\
$\begin{array}{l}\text { Private pre- } \\
\text { primary schools }\end{array}$ & 120 & 36 & 135 \\
\begin{tabular}{l} 
Total \\
\hline
\end{tabular} & 150 & 45 & 153 \\
\hline
\end{tabular}

Table 2 shows different school homework activities assigned to children in both public and private pre-primary schools. From the table, it is evident that pre-primary school children were assigned various school homework activities by their teachers as a method of teaching-learning. The findings given indicate that $24 \%$ of the teachers assigned homework focused on number work and language activities. There were some teachers $(21 \%)$ who assigned work from what was taught during the day. Eight of the respondents assigned homework comprising modeling, writing of numbers and alphabetical letters. Seven pre-school teachers assigned homework in language activities alone. Four teachers assigned reading, number work, Kiswahili, shading and coloring activities. The findings indicate that Science experiments combined with filling in of blank spaces 
were only assigned by three respondents. The current study findings show that the least assigned activities were combination of coloring pictures, sound recognition and writing through tracing by two respondents as well as the activity of answering written questions or exercises from textbooks. It was therefore revealed that most teachers failed to distribute homework activities in all subjects learnt. The study findings clearly imply that the most common school homework activities assigned by the respondents were related to number work and English language activities. These findings agree with the findings by Cooper ${ }^{14}$ who did a study on school homework and indicated that age appropriate pre-primary school homework ideas include applying colour to pictures, writing their names several times or listing items that start with a specific letter (Table 2).

Table 2 Reasons why pre-primary school teachers did not assign schoo homework to children in their classes

\begin{tabular}{lll}
\hline $\begin{array}{l}\text { Reasons for not assigning school } \\
\text { homework }\end{array}$ & Frequency & Percent \\
\hline $\begin{array}{l}\text { Not applicable (Those who assigned } \\
\text { homework) }\end{array}$ & 114 & 95 \\
$\begin{array}{l}\text { Children should choose what to do } \\
\text { Children relax after school }\end{array}$ & 2 & 2 \\
$\begin{array}{l}\text { So as not to strain children's growing } \\
\text { brains }\end{array}$ & $\mathrm{I}$ & $\mathrm{I}$ \\
$\begin{array}{l}\text { We finish our syllabus early } \\
\text { Total }\end{array}$ & $\mathrm{I}$ & $\mathrm{I}$ \\
\hline
\end{tabular}

\section{Duration for homework completion}

The respondents were asked to state time that they gave pre-primary school children to complete the given homework. The responses were as presented in Table 3 . It was observed that majority of the pre-primary school teachers $(61 \%)$ gave school homework that would not exceed between 10-15 minutes, while $28 \%$ gave school homework which was expected to be completed in more than 15 minutes. The study findings are consistent with findings of a study conducted by Cooper ${ }^{16}$ who reported that all daily homework assignments combined should take about 10 minutes multiplied by the grade level of the learner. He also added that when reading is included as a type of homework the 10 minutes might be increased to 15 minutes (Table 3).

\section{Completion of the assigned homework by all the children}

The study sought to establish whether children completed given assignments or not. The responses were as presented in Figure 5. Almost three quarters of the respondents reported that not all children completed the assigned school homework with slightly more than a quarter of them saying that all their children completed the assigned school homework. The findings show that most children did not complete given homework (Figure 5).

\section{E. Issues on completion of homework}

The teachers were asked to name possible factors that affect completion of homework assigned. Table 4 presents the findings. Some (43) respondents claimed that some parents did not assist their children with homework while 6 respondents indicated that, due to age factor their children used to forget what they were taught. Other respondents gave different factors that affect homework completion. The study findings indicate that not all pre-primary school children were able to complete given school homework (Table 4).

Table 3 Homework activities assigned to children

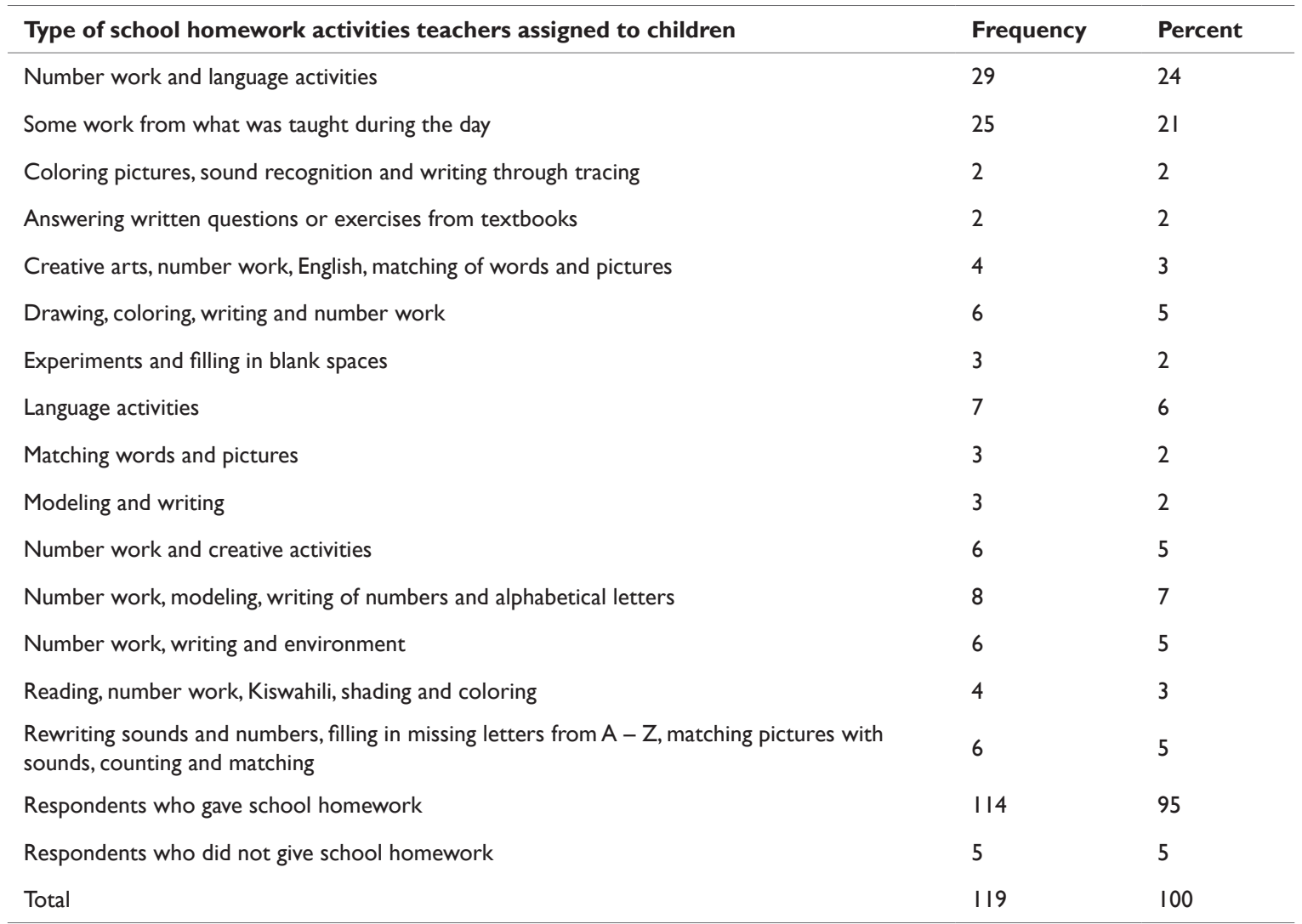


Table 4 Duration given to children to complete assigned school homework

\begin{tabular}{lll}
\hline Duration & Frequency & Percent \\
\hline Less than 10 minutes & 13 & 11 \\
10-15 minutes & 73 & 61 \\
16 \& above minutes & 33 & 28 \\
Total & 119 & 100 \\
\hline
\end{tabular}

Table 5 Factors that affect completion of homework assigned

\begin{tabular}{|c|c|c|c|}
\hline \multicolumn{2}{|c|}{ Factors } & \multirow{2}{*}{$\begin{array}{l}\text { Frequency } \\
35\end{array}$} & \multirow{2}{*}{$\begin{array}{l}\% \\
29\end{array}$} \\
\hline \multirow{12}{*}{ Valid } & $\begin{array}{l}\text { Not applicable (Those who complete } \\
\text { homework) }\end{array}$ & & \\
\hline & Because the ability is not the same & I & 1 \\
\hline & $\begin{array}{l}\text { Due to their age they forget what they } \\
\text { were taught }\end{array}$ & 6 & 5 \\
\hline & $\begin{array}{l}\text { Early retirement to bed and interference } \\
\text { by TV programmes }\end{array}$ & I & I \\
\hline & Forgetting, lack of pencils \& books & I & I \\
\hline & Lack of enough learning facilities & I & I \\
\hline & $\begin{array}{l}\text { Some parents don't assist their children } \\
\text { with it }\end{array}$ & 51 & 43 \\
\hline & Lack of time because of play & 2 & 2 \\
\hline & $\begin{array}{l}\text { Some are assigned some duties after } \\
\text { school while others are just lazy }\end{array}$ & 8 & 6 \\
\hline & Some children don't care about homework & I & I \\
\hline & They feel tired after school & 12 & 10 \\
\hline & Total & 119 & 100 \\
\hline
\end{tabular}

assigned activities related to number work and English language while applying colour to pictures was among the least assigned activities. When children were assigned with school homework, majority of the respondents expected them to complete it between ten and fifteen minutes. However, there were some children who did not complete their homework assignments especially those who were not assisted by their parents.

\section{Conclusion}

Most teachers from both public and private pre-primary schools were using school homework as a method of teaching-learning. The few teachers who did not assign homework had a view that children did not need extra school work at home. It was found that not all teachers were trained on use of school homework and therefore not all assigned homework to children. It was evident that some of the subjects taught in pre-primary schools were ignored since children were rarely given homework relating to all of them. It was concluded that there were various factors that affected completion of homework assigned to children including that some parents never assisted their children when doing homework.

\section{Recommendations}

\section{a) For parents}

The findings revealed that most parents demanded for daily school homework for their children. There is need for parents to be sensitized by the school administrators on ECDE teaching guidelines required for pre-primary school children. They should also be advised that use of school homework is not the only option for academic progress for their children.

\section{b) For private school managers and public school head teachers}

It was established in this study that most school administrators appreciated school homework. They should therefore collaborate with District Centre for Early Childhood Education (DICECE) to organize sensitization workshops for them and their teachers on the impact on use of school homework as a teaching-learning method. School administrators should also ensure regular monitoring of teachinglearning methods is done in the appropriate manner as prescribed by ECDE guidelines.

\section{Acknowledgments}

None.

\section{Conflicts of interests}

Author declares that there is no conflict of interests.

\section{References}

1. Cameron L, Bartel L. The researchers ate the homework! Perspectives of parents and teachers. Education Canada: Toronto. 2009.

2. Cooper H, Lindsay JJ, Nye B, et al. Relationships among attitudes about homework, amount of homework assigned and completed and students' achievements. Journal of Educational Psychology. 1998:90(1):70-83.

3. Murungi CG, Muthee J. Relationship among intelligence, achievement motivation, type of school, and academic performance of kenyan urban primary school pupils. 4th ed. Encyclopedia of Information Science and Technology. 2017.

4. Patall EA, Cooper H, Wynn SR. The effectiveness and relative importance of choice in the classroom. Journal of Educational Psychology. 2010;102:896-915 
5. Vatterott C. Rethinking homework: Best practices that support diverse needs. Alexandria.VA:ASCD. 2009.

6. Vatterott C. Becoming a middle level teacher. Student focused teaching of early adolescents. New York: McGraw-Hill. 2007.

7. Loveless T. The brown centre annual report on American education: Part II. Do students have too much homework? Washington, DC: Brookings Institution Press. 2003.

8. Bennet S, Kalish N. The case against homework: how homework is hurting our children and what we can do about it. New York: Crown Publishers. 2006.

9. Kohn A. The homework myth: Why our children get too much of a bad thing. Combridge MA, editor. Da Capo Press. 2006.

10. Kralovec E, Buell J. End homework now. Educational Leadership. 2001:58(7):39-42.

11. Xu J. Predicting homework time management at the secondary school level: A multilevel analysis. Learning and Individual Differences. 2010;20:34-39.
12. Zimmerman BJ, Kitsantas A. Homework practices and academic achievement: The mediating role of self-efficacy and perceived responsibility beliefs. Contemporary Educational Psychology. 2005;30:397-417.

13. Kralovec E, Buell J. The end of homework: how homework disappoints families. Overburdens Children and Limits Learning. Boston: Beacon Press. 2000.

14. Cooper H. The battle over homework, Thousands Oaks. CA:Corwin Press. 2006

15. Orodho AJ. Elements of Education and Social Science Research Methods. Maseno:Kanazja Publisher. 2009.

16. Cooper H. The Battle Over Homework: Common ground for administrators, teachers and parents. 3rd ed. Thousand Oaks, CA:Corwin Press. 2007. 